\title{
The impact of urban planning on the citizens and property safety: A case study of a university campus
}

\author{
Viktor Šoltés ${ }^{1[0000-0002-2237-2249]}$, Richard Jankura ${ }^{20000-0002-7100-563 X]}$, Ladislav Mariš ${ }^{3[0000-}$ \\ 0003-4952-9055] and Zuzana Zvaková ${ }^{40000-0003-1560-4037]}$ \\ 1,2,3,4 University of Zilina, Univerzitna 8215/1, 01026 Zilina, Slovakia \\ viktor.soltes@fbi.uniza.sk
}

\begin{abstract}
In recent years, there has been an increasing emphasis on urban planning, which helps cities to adapt to new challenges. Sustainability of cities is one of the basic requirements for local and regional planning, especially from an environmental point of view. One of the many challenges for cities is the safety of citizens and reducing crime in cities. It is important to realize that the environment and urban development can have an impact on the safety of citizens and the development of crime in cities. One of the best-known concepts that uses space modification to reduce crime is the concept of CPTED (Crime Prevention Through Environmental design). It is based on the simple idea that crime is the result of opportunity, and by changing the physical environment, a reduced incidence of crime can be achieved. The article will describe the theoretical framework of the CPTED concept, the characteristics of its principles and the elements it contains. The aim of the article is to assess the general principles of crime prevention using environmental design, and their elements, which are applied on the campus of the University of Žilina in Žilina. Subsequently, possible shortcomings of the concept for the selected case study will be evaluated and new solutions will be proposed. The results of the article will be intended primarily for designers and architects who are responsible for maintaining a safe and friendly environment on the university campus.
\end{abstract}

Keywords: CPTED, Safety, Urban planning, Environment built, Crime prevention.

\section{Introduction}

The unstoppable development of cities brings with it several challenges. Whether it is sustainable urban development or improving the quality of life [1]. One of the important areas that needs to be ensured within the "Smart City" is the safety of citizens and their property. It is possible to think about solving this challenge in a broader context, already in the architectural (urban) planning of buildings and their surroundings. The link between the built environment and human behavior has been the subject of much research for a long time [2] [3] [4]. In particular, it concerns the assessment of the link between the built environment and human physical activity, which may also have an impact on overall safety and security [5]. 
There are several terms, that are associated with the solution of the urban environment and its adaptation to the needs of safety and security. "Urban design" usually refers to the design of a city and its physical elements, including its layout and appearance, and refers to the function and attractiveness of public spaces [5,6].

"Built environment" includes urbanism, land use and the transport system and includes patterns of human activity in the physical environment. The built environment is constantly changing in countless ways; some changes are fast (e.g. the decline of pedestrians on the street) or slow (e.g. the appearance of the exterior of the building after decades) [5]. Environmental design deals with the reflection of architecture in a specific environmental, cultural, social and historical context. Conceptual designs of this design can be used in the fight against crime [4].

It is important to realize that the "Urban Space" is a center that, on the one hand, generates a wide range of social, cultural, economic, political and environmental problems, but on the other hand ensures the most creative changes, innovations and development impulses. It is a place where the main conflicts and contradictions of the present occur and present, but also a place that should significantly help to manage these conflicts [8]. In the urban environment, it is possible to define terms such as $[8,9,10]$ :

- Crime attractors are specific places that create an opportunity for the offender to commit a crime. Such spaces include large shopping centers, bus and train stations, affluent neighborhoods, remote and sparsely populated areas, etc.

- Crime Detractor is a place that deters offenders and prevents committing crime. Such places are characterized by sufficient control and a suitable system of protection and can be also referred to as Crime-neutral areas.

- Crime generators are places where a large number of people occur. These are places that produce crime in a given locality, because potential criminals meet there. It can be bars, discos, etc. Offenders who can commit crimes come out of these places. These are places where many people are, but they do not have a predetermined motivation and act according to crime opportunities [7].

Several concepts are devoted to the solution of creating a safety and security environment. The Secure by Design (SBD) program has been created in United Kingdom. The program provides architectural and security assistance for various environments. The program works on several principles, which are based on environmental protection. It includes an integrated approach, environmental quality and ownership, natural surveillance, accesses and walkways, open spaces and management, and lighting.

According to "Secured by Design", the aim of organizations is to focus on the following basic steps to achieve a "Secured Environment [2]:

- Commitment - the organization and its management is decided to participate in the Secured Environment,

- Understanding - the organization understands the security risks it faces,

- Response - the organization provides an effective response to reduce the risks to the organization,

- Management - the organization needs to have a plan in place to achieve its aims and objectives, 
- Implementation - the organization implements security measures,

- Evaluation - the organization monitors and evaluates the security measures.

Many threats arise in the urban environment. Appropriate spatial planning and urban planning can provide solutions that can reduce vulnerability to expected threats. There are several concepts for this purpose, but among the most used is the concept of CPTED (Crime Prevention Through Environmental Design).

\section{Crime prevention through environmental design}

In Slovakia, crime is considered to be a conduct that is a criminal offense. Crime prevention therefore is a targeted, planned, coordinated and comprehensive response to the causes and conditions that create or enable crime and other anti-social activities, with the aim of preventing, suppressing and avoiding them; this also applies to the prevention of other anti-social activities [11].

\subsection{Creation of CPTED concept}

The origins of crime prevention in urban planning and architectural design date from the 1950 s to the 1970s. It turned out that changing physical design, communities, homes and businesses could affect crime. By changing the physical design, more complicated criminal activity can be achieved. The change may increase the risk of detecting the offender of the crime [12].

In the 1960s, Elizabeth Wood developed guidelines to address safety issues, with an emphasis on design elements that would support natural surveillance. This guideline was never implemented, but stimulated some of the ideas that led to CPTED. In 1972, Newman defined the concept of the so-called "Defensible space", which was the basis for the idea of the CPTED concept. Newman identified four elements of defensive space - territoriality, natural surveillance, image and milieu. Jeffery (1971) was the first to use CPTED concept and emphasized urban planning for crime control and prevention [13]. Later, other possibilities for the CPTED concept were formed, and finally the second (2004) and third generation (2011) emerged [10,14]. Crowe (2000) focused on routine factors that could be influenced by environmental design to reduce the probability for potential offenders to commit crime [15]. According to Crow, the proper design and effective use of the built environment can lead to a reduction in the fear of crime and in the occurrence of crime and thus to an improvement in the quality of life [16].

The International CPTED Association defines CPTED concept as a multidisciplinary approach to crime prevention that uses urban and architectural design and the management of built-up and natural environments. The strategy aims to reduce victimization, deter offenders, and build a sense of community feeling among the population, reduce crime and minimize the fear of crime [17].

There is no doubt that the form and layout of the built environment have a huge impact on the opportunity to commit a crime, or at least potentially on thinking about 
crime prevention. There are many crimes and the characteristics of these places in terms of their overall layout and their specific attributes have a very significant impact on criminal offenses [18]. However, the second challenge is to adapt such space not only to reduce crime, but also to improve everyday life [19].

\subsection{Principles of the CPTED concept}

The CPTED concept is based on several principles that can be applied in the design of a suitable environment. The emphasis is on crime prevention rather than catching and punishing the offender. The concept is mainly focused on increasing territoriality, surveillance and legitimate use of space, or the determining of territory [20]. There are three basic principles of the CPTED concept, namely mechanical measures, organizational or human measures and natural measures [16,21]. Some other theories later identified other extended principles of CPTED, which includes principles such as: access control, support activities, and target hardening. Some principles may overlap among authors [10].

Ensuring natural surveillance and control of the environment - based on keeping the offender "in sight", under constant surveillance. This can be ensured by the correct direction of the windows, street lighting and various landscaping. Natural surveillance provides a visual overview of observing the surroundings of objects. If the offender is identified from the outside as well as from the inside, it will be more difficult for him to commit a crime. Natural surveillance can be provided in two ways - formal or informal. Formal elements of surveillance can include CCTV (Closed Circuit Television), lighting, monitoring, observation, physical protection, etc. However, the CPTED concept focuses more on informal surveillance, where it is possible to include clear orientations, open streets, physical design, use of space, etc. $[6,8,10]$.

Natural access control - the main principle is to limit access points to a potential offender, to create a certain perception of risk in the offender, on the basis of which he would not dare to commit a crime. It can be provided in the form of various natural elements (modified shrubs, trees, etc.), which would direct the movement. Controlled access also includes formal elements (e.g. gates) or mechanical elements of the building (locks, doors, windows, etc.) $[6,8,10]$.

Visible delimitation of territory (territoriality) - achieving a clear differentiation of public and private space. A visible delimitation of the territory can be ensured by means of suitable structural elements or symbolic barriers to perimeter protection [8]. If it is not possible to use mechanical elements, it is possible to use a division of space. This will define the boundaries of private and public spaces.

Space maintenance - this principle is based on the premise that if the area around the building is maintained, it discourages the perpetrator from committing a crime, as he feels that the space is taken care of, and increases his risk of being caught $[8,10]$. 


\section{$3 \quad$ Methodology}

The article focuses on the ability and possibilities of using the CPTED concept on a specific example. This is the campus of the University of Žilina in Slovakia. Through field research, it was necessary to gather information about the selected environment so that we could specify the principles of environmental design on a specific case study. In the practical part of the article, the architecture of the University of Žilina campus was analyzed by observation. After evaluating the particular principles, possible conflicts with the principles of the CPTED concept will be outlined. Among the basic principles through which we will evaluate compliance with the CPTED rules belong territorial reinforcement, natural surveillance, natural access control and image management. It is the CPTED concept that can be one of the approaches to school safety. In addition to crime prevention, this approach offers the potential advantage of improving the perception of safety and security among people on its campus [22].

\section{$4 \quad$ Results and discussion}

In the outdoor environment, it is possible to identify places that can be defined as a crime attractor, crime detractors, or crime generators. The campus of the University of Žilina was chosen as a potential crime attractors place for our case study. This is a place that can be a target for potential criminals. Farther, observance to selected principles of the CPTED concept will be assessed for the selected object.

The University of Žilina in Žilina is in one of the largest cities in Slovakia, namely in Žilina with a population of 82,660 as of 31 December 2019 [23]. There is also a law enforcement department in the city of Žilina, which acts in ensuring general matters of public order, environmental protection in the municipality and fulfilling tasks arising from generally binding regulations of the municipality, resolutions of the municipal council and decisions of the mayor [24]. This is the Žilina Municipal Police, which, like any other municipal polices, publishes an annual report on its activities. On the basis of the Activity report of the Žilina Municipal Police in 2018, it can be stated that as of 31 December 2018, there were 80 members of the Žilina Municipal Police [25]. The basic tasks of the municipal police include ensuring public order in the municipality and detecting and clarifying offences. The offenses are reported to the municipal police by the citizens of the city or they are detected by their own activity [26].

In addition to detecting and resolving offenses, the city police also search for persons for whom a search has been declared. In 2018, the Municipal Police managed to track down a total of 27 people. Members of the city police can also use coercive means in their activities. In 2018, the Žilina Municipal Police recorded 7,363 cases of the use of coercive means and technical means to prevent the departure of the vehicle. Personal freedom was restricted to 88 persons by the intervention of a member of the Municipal Police, of which 54 persons were transferred to the Žilina Municipal Police Department and 7 to the Police Corps Department. In 2018, one case of an attack on a member of the Žilina Municipal Police was also recorded [25]. 
Table 1. Statistics on the resolution of offenses by the Žilina Municipal Police in 2018 [25]

\begin{tabular}{|c|c|c|c|}
\hline Offences & Detected & Reported & Total \\
\hline Business offences & 26 & 9 & 35 \\
\hline $\begin{array}{c}\text { In the area of protection against alcoholism and } \\
\text { other drug addictions }\end{array}$ & 40 & 5 & 45 \\
\hline Against public order & 994 & 430 & 1,424 \\
\hline Property offences & 17 & 10 & 27 \\
\hline In the field of transport & 11,250 & 4,821 & 16,071 \\
\hline Generally binding regulation of the municipality & 1,466 & 673 & 2,139 \\
\hline Against the protection of non-smokers & 500 & 153 & 653 \\
\hline Other offences & \multicolumn{2}{|c|}{332} & 332 \\
\hline Total & 14,293 & 6,101 & 20,726 \\
\hline
\end{tabular}

The University of Žilina is a modern university with more than 65 years of history. More than 7,728 students are currently studying at the University. The campus of the University of Žilina consists of several buildings, green spaces and parking lots. The following picture shows an orientation map of the campus of the University of Žilina.

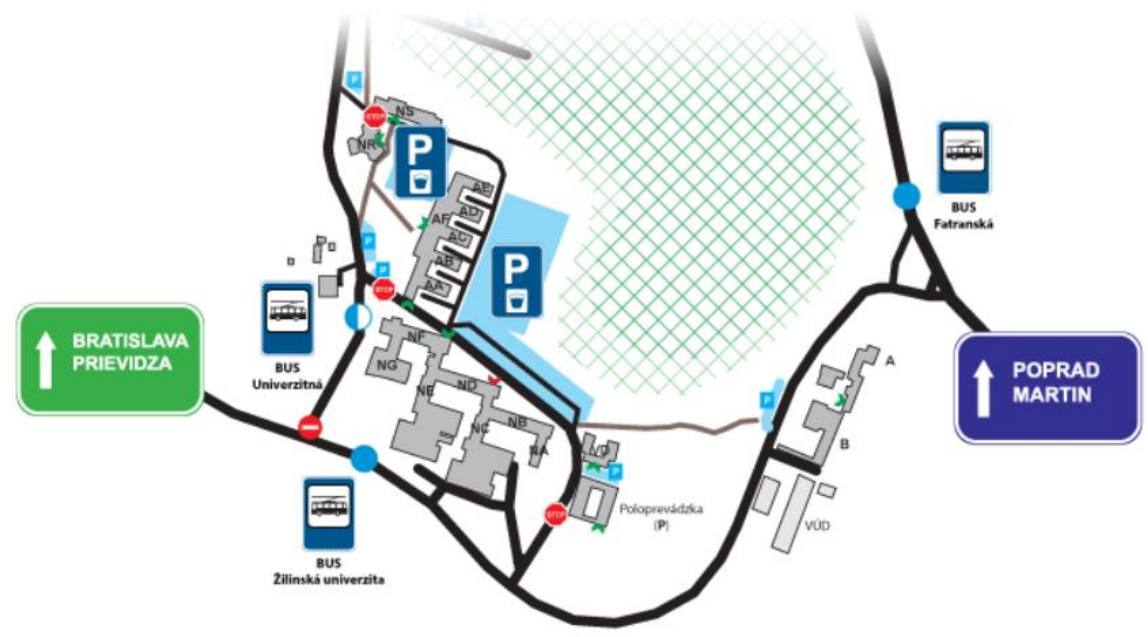

Fig. 1. Map of the University of Žilina campus

The campus consists of the buildings of individual faculties and the science park. The campus is located outside the built-up area of the city. Access to the campus of the University of Žilina is possible from several sides, by public transport, by car or on foot. The university campus is mostly surrounded by greenery and one adjacent organization. In front of the main building of the Rectorate, there is an open space, which 
consists of a relaxation zone with benches, a fountain and a statue. In addition to the sidewalks and the central courtyard, there are also lots of greenery, trees, lighting, and baskets. The following picture shows a front view of the campus and the rectorate's building.

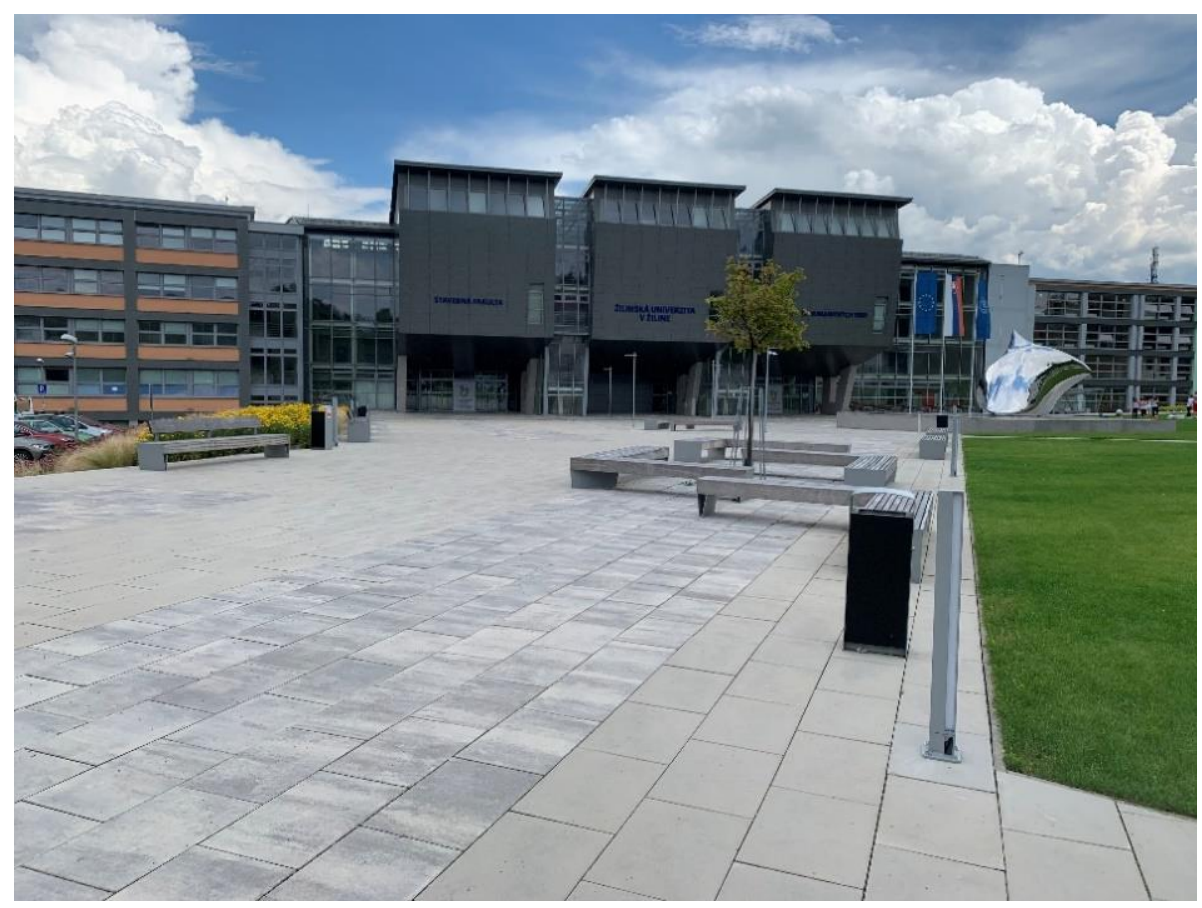

Fig. 2. A front view of the campus and the Rectorate's building

In the following section, the principles of the CPTED concept on the selected object will be assessed.

\subsection{Application of the CPTED on a selected case study}

Schools, universities, and their campuses are specific places, and ensuring their protection can be difficult. It is mostly a semi-public space in which many people fluctuate. It has been shown that the CPTED concept can be one way of discouraging criminals from committing a crime in such places. However, it is important to decide against which threat the school should be protected. Threats can be external (external persons) or internal (students, employees). The CPTED concept mainly affects external threats.

Among the general principles of the CPTED concept, which are most relevant to school design, can be included: Territoriality, Natural Surveillance, Natural access control, and Maintenance (Image/Space management) [27, 28]. The following table shows the elements of the individual CPTED principles, which were qualitatively evaluated on a selected object $[10,27,29,30,31,32]$. 
Table 2. The elements of the CPTED principles

\begin{tabular}{cccc}
\hline Territoriality & Natural Surveillance & Access control & Maintenance \\
\hline Symbolic barriers & Placement of win- & Mechanical Access & Routine maintenance \\
Real barriers & dows & control & Graffiti \\
Private parking & Location of entrances & Strong Windows & Vandalism \\
Sidewalks & Physical design & Entry Guards & Broken windows \\
Signs & Clear Sightlines & Number of entrances & Physical design \\
Landscaping & CCTV & Visibility of en- & Street lighting \\
& trances & Baskets \\
& Gtreet lighting & Physical barriers & Landscape \\
\hline
\end{tabular}

Territoriality. The campus of the University of Žilina can be included among the semipublic space, which can be accessed throughout the day. Therefore, it is used not only by students but also by the general public. The campus does not have any mechanical barriers on the perimeter, but the boundaries of the space are clearly defined. Territoriality is enhanced by property lines in the form of sidewalks, planting greenery and curbs around the driveway and signs. The entrance to the parking lot is secured by a barrier, which increases the territoriality of the campus area. They work on the use of classic control or contactless media (RFID transponder cards, UHF tags or ticket with magnetic stripe). Simple software and cloud solutions are the main benefits of a parking system.

Natural Surveillance. The envelope of buildings in the campus consists mostly of windows. This ensures natural surveillance inside, but also on the entire area in campus. The campus area is very clear, and there are only few places where crime could occur. The main entrance to the rectorate's building is visible from the adjacent area and the street, which provides natural surveillance. Other entrances to individual buildings are visible from adjacent places. The campus complex has standard street lighting, which provides natural surveillance of the entire campus area during the night. Specifically, these are LED reflectors with IP $68,38 \mathrm{~W}$, or $48 \mathrm{~W}$. Formal surveillance of the whole campus area is provided by CCTV. The CCTV is built on IP technology with one center for control, recording, and management. Signal transmission is secured via IP infrastructure (TCP/IP network $100 \mathrm{Mb} / \mathrm{s}$ ) and then to the recording device NVR (server with RAID). CCTV uses several types of cameras (BOSH), depending on the purpose. BOSH DINION IP 8000 MP with high resolution 1920 x 1080 px and can work in low light conditions. The second type of camera is BOSH FLEXIDOME IP panoramic 7000 MP. It is a panoramic camera, with a 180- or 360-degree overview. The camera has 12 $\mathrm{MP}$ and $30 \mathrm{fps}$ and has a Full HD resolution. The maximum range of up to $55 \mathrm{~m}$, for detect. Another camera is a ceiling camera, BOSH FLEXIDOME IP outdoor $5000 \mathrm{MP}$ IP. The camera has $5 \mathrm{MP}$, with a resolution of $2592 \times 1944 \mathrm{px}$. It uses a CMOS sensor type and the angle of rotation is 330 degrees. All cameras are designed for outdoor use, with IP66 protection. There is no guard on campus. 
Natural Access Control. As the campus is a semi-public space, it is very difficult to control the entry of all persons into the object. Two main entrances from the front and five entrances from the back lead to the Rectorate building. The entrance through the main entrances is partially controlled by the concierge. However, the building has several entrances that are not controlled and can be used by a potential offender to enter the building. Individual rooms in the campus buildings are locked. Some entrances to the building within the campus are controlled using RFID cards held by students, teachers, and university staff. Outside working hours, all entrances to the buildings are locked. Several driveways and sidewalks lead to the campus. It is possible to get to the campus by car from two different directions which are secured by a barrier. For pedestrians, access is possible from several sides. Rectorate building has several entrances, especially in the rear of the building, which can be used without further control during operating hours. These entrances are not visible from the side buildings, but it is possible to see them from the adjacent parking lot.

Maintenance. Maintenance (respectively Image Management) seeks to promote a positive image of the built environment. The campus has good maintained landscaping and buildings. There isn't evidence of graffiti, polluted areas, or "broken windows" on campus. The surroundings of the campus are completed by well-maintained greenery in the area, such as lawns, trees, or shrubs. In front of the main building is a square, which is complemented by new benches, baskets, and street lighting, which completes the feeling of a well-maintained environment. There are precisely defined areas for smokers, bicycles, and cars. The following image shows a well-maintained campus space.

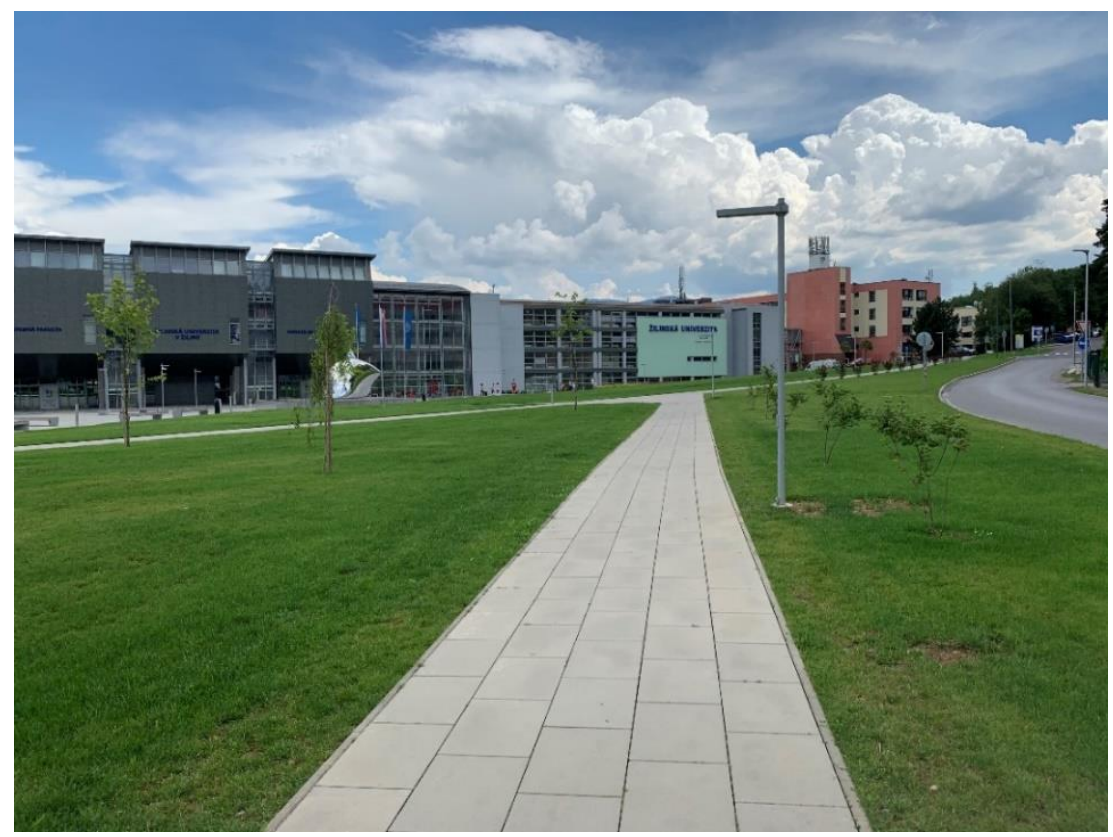

Fig. 3. Maintained campus space 
The CPTED concept is one of the ways to reduce crime in selected places and improve the quality of life. In the previous part, the principles on a specific object were qualitatively evaluated, where the application of several elements of the CPTED concept was demonstrated. However, the safety of school facilities is a very complex process, and the CPTED concept is only one way to improve their safety.

\section{Conclusion}

Urban planning deals with the quality of the urban environment and how the built form affects everyday life. In this regard, the issue of crime in urban development is gaining more and more prominence. Based on this, several concepts have emerged, which can be used to effectively use the built environment, which can lead to a reduction in the incidence of crime in the environment. One of the most widespread concepts dealing with this issue is CPTED. Using the principles, it recommends, it is possible to influence the physical environment and thus achieve a reduction in crime, but also to contribute to improving the quality of life. These are the principles of natural surveillance, the definition of the territory, the maintenance of the environment, and the natural access control. By adhering to these principles and the elements they contain, it is possible to achieve a reduction in crime in the area.

The case study, in which the principles of the CPTED concept were evaluated, highlighted many strengths of the selected place. Many principles of the CPTED concept were adhered to at a high level, whether it was territoriality, natural surveillance, natural access control, or image management. However, it is important to note that the area, which is the campus of the University of Žilina, is a semi-public place visited by many people. There are several side entrances to the campus that are not controlled by the access control system. This creates the possibility of an uncontrolled entry of a potential criminal into the building. Of course, there is a conflict of interest here, as it is very difficult to control every entrance to a building in such buildings. However, the campus of the University of Žilina can be a suitable example of the application of the principles of the CPTED concept.

Conflicts can also arise when using the principles of the CPTED concept. It can go e.g. o delimiting the territory by walls, thus ensuring territoriality but worsening natural surveillance. It is important to realize that the premises of universities and schools, in general, are becoming soft targets against violent crime, and it is also possible to prevent selected types of attacks with this concept, as it increases the risk of detecting the offender and reduces his opportunity.

\section{Acknowledgements}

This paper was supported by project VEGA 1/0768/19. 


\section{References}

1. Stofkova, Z., Stofko, S: Some indicators of quality of life in a globalized world. In: Kliestik, T. (ed.) 16th International Scientific Conference on Globalization and its Socio-Economic Consequences, pp. 2127-2134. University of Zilina, Rajecke Teplice, Slovakia (2016).

2. Secured by Design, https://www.securedbydesign.com/guidance/interactive-design-guide, last accessed 2020/06/21.

3. Casteel, C., Peek-Asa, C.: Effectiveness of crime prevention through environmental design (CPTED) in reducing robberies. American Journal of Preventive Medicine 4(18), 99-115 (2000).

4. Al Husban, S. A. M., Al Husban, A. A. S.: The role of built environmental design in violence prevention in universities' campuses: Al al-Bayt Universtiy in Jordan as a case study. Property Management. (2020).

5. Handy, L. S., Boarnet, M., Ewing, R., Killingsworth, R.: How the built environment affects physical activity: Views from urban planning. American Journal of Preventive Medicine 2(23), 64-73 (2002).

6. Lak, A., Hasankhan, F., Garakani, S.A. Principles in practice : Toward a conceptual framework for resilient urban design. Journal of environmental planning and management 63(12), 13246-13262 (2020).

7. Hofreiter, L.: Bezpečnostné prostredie súčasného sveta. Radim Bačuvčík - VeRBuM, Zlín (2016).

8. Hofreiter, L.: Manažment ochrany objektov. 1nd edn. EDIS/ Žilinská univerzita v Žiline, Žilina (2015).

9. Brantingham P., Brantingham, P.: Criminality of place: Crime Generators and Crime Attractors. European Journal on Criminal Policy and Research, 6-25 (1995).

10. Cozens P., Love, T.: A Review and Current Status of Crime Prevention through Environmental Desing (CPTED). Journal of Planning Literature, 1-20 (2015).

11. Slov-Lex, https://www.slov-lex.sk/pravne-predpisy/SK/ZZ/2008/583/20191201, last accessed 2020/06/23.

12. Armitage, R., Monchuk, L. What is CPTED? Reconnecting Theory with Application in the Words of Users and Abusers. Policing-A Journal of Policy and Practice 13(3), 312-330 (2019).

13. Jeffery, C. R.: Crime prevention through evironmental design. Sage Publications, Beverly Hills, CA (1971).

14. Lab, S. P.: Crime Prevention - Approaches, Practices, and Evaluations. 5th edn. Routledge, New York (2020).

15. Crowe, T.: Crime Prevention through Environmental Design: Applications of Architectural Design and Space Management Concepts. 2nd edn. Butterworth-Heinemann, Oxford, UK (2000).

16. Crowe, T.: Crime Prevention through Environmental Design: Applications of Architectural Design and Space Management Concept. Butterworth-Heinemann, Boston, MA (1991).

17. International CPTED Association, https://www.cpted.net/, last accessed 2020/05/26.

18. Schneider, R. H., Kitchen, T.: Crime Prevention and the Built Environemnt. 1nd edn. Routledge, Oxon (2007).

19. Kubas, J., Velas, A., Siser, A.: Implementation of Multi-Criteria Decision Making as the Method Used to Achieve Optimal Level of Security in Local Municipalities. In: Zhang, H. (ed.) 4th ICMIBI International conference on training, education, and management, ICMIBI-TEM 2017, vol. 83, pp. 371-375. Singapore management \& sports science inst., Dubai, United Arab Emirates (2017). 
20. Newman, O.: Defensible Space: People and Design in the Violent City. Architectural Press, London, UK (1973).

21. Molaeri, P., Hashempour, P. Evaluation of CPTED principles in the housing architecture of rural areas in the North of Iran (Case studies: Sedaposhte and Ormamalal). International Journal of Law Crime and Justice 62, (2020).

22. Shariati, A., Guerette, R. T.: Resident Students' Perception of Safety in On-Campus Residential Facilities: Does Crime Prevention through Environmental Design (CPTED) Make a Difference? Journal of School Violence 4(19), 570-584 (2019).

23. Statisticky urad Slovenskej republiky, https://www7.statistics.sk/PortalTraffic/fileServlet?Dokument=67704ddc-63f9-4826-89b7-75ccc9fcf185, last accessed 2020/06/01.

24. Slov-Lex, https://www.slov-lex.sk/pravne-predpisy/SK/ZZ/1991/564/, last accessed 2020/06/01.

25. Mesto Žilina, https://www.zilina.sk/dokumenty/DokumentyProgramyMZ_20190619152802.pdf, last accessed 2020/06/01.

26. Misik, J., Kubas, J.: Safety management as a support activity in the local self-government. In: Hajek, P., Vit, O., Basova, P., Krijt, M., Paszekova, H., Souckova, O., Mudrik, R. (eds.) CBU International conference proceedings, CBUIC 2017, vol. 5, pp. 728-731. Central Bohemia Univ., Prague, Czech Republic (2017).

27. Schneider, T.: Crime prevention through environmental design-The fundamentals for schools. National Clearinghouse for Educational Facilities. https://files.eric.ed.gov/fulltext/ED511746.pdf, last accessed 2020/05/16.

28. Lamoreaux, D., Sulkowski M. L.: An alternative to fortified schools: Using crime prevention through environmental design (CPTED) to balance student safety and psychological wellbeing. Psychology in the Schools 1(57). (2019).

29. Kampova, K., Lovecek, T.: Uncertainty in Quantitative Analysis of Risks Impacting Human Security in Relation to Environmental Threats. In: Mesko, G., Dimitrijevic, D., Fields, C. B. (eds.) NATO Advanced Research Workshop on Managing Global Environmental Threats to Air, Water and Soil - Examples from South Eastern Europe, pp. 349-363. Springer, Ljuljana, Slovenia (2010).

30. Lab, S. P.: Crime Prevention - Approaches, Practices, and Evaluations. 5nd edn. Routledge, New York (2020).

31. Molaei, P., Hashempour, P.: Evaluation of CPTED principles in the housing architecture of rural areas in the North of Iran (Case studies: Sedaposhte and Ormamalal). International Journal of Law, Crime and Justice 60, (2020).

32. Crime Prevention Through Environmental Design (CPTED) School Assessment (CSA), https://rems.ed.gov/docs/CDC_CPTEDSchoolAssessment.pdf, last accessed 2020/06/26. 